\title{
Deradikalisasi organisasi kemahasiswaan di perguruan tinggi Muhammadiyah Aisyiyah Daerah Istimewa Yogyakarta
}

\author{
Muhammad Salisul Khakima,1,* \\ ${ }^{a}$ Universitas Aisyiyah Yogyakarta \\ ${ }^{1}$ muhammad.salis@unisayogya.ac.id \\ * Korespondensi penulis
}

\begin{abstract}
ABSTRAK
Penelitian ini bertujuan untuk menjelaskan proses deradikalisasi mahasiswa pada organisasi kemahasiswaan, yaitu Ikatan Mahasiswa Muhammadiyah di bawah pembinaan Perguruan Tinggi Muhammadiyah Aisyiyah (PTMA). Paham dan gerakan radikal yang identik dengan fanatisme terhadap ajaran Islam mulai berkembang pasca era reformasi, namun keberadaannya tidak sejalan dengan ideologi Pancasila, bahkan mengancam eksistensi dasar negara tersebut. Mahasiswa sebagai generasi muda memiliki potensi terhadap ancaman paham dan gerakan ini, sehingga satuan pendidikan tinggi yang berlatar belakang ajaran Islam memiliki peran penting dalam pembinaan melalui lembaga kemahasiswaan. Perguruan tinggi berbasis nilai-nilai Islam dan Kemuhammadiyahan telah berkontribusi besar dalam menghasilkan lulusan generasi muda dan membangun negara. Pembinaan IMM sebagai organisasi kemahasiswaan ini dimaksudkan agar mahasiswa sebagai generasi penerus bangsa dapat berperan dalam membangun bangsa tanpa bertentangan dengan ideologi Pancasila, selain itu juga tetap berdasarkan pada nilai-nilai Islam yang tidak radikal. Penelitian ini menggunakan metode pendekatan kualitatif, dengan sumber data primer dan sekunder. Data primer diperoleh dengan melakukan wawancara mendalam dengan pimpinan PTMA dan IMM, sedangkan data sekunder diperoleh dengan mencari studi literatur berupa buku, jurnal, dan dokumen-dokumen lain yang terkait dengan deradikalisasi dan peran PTMA. Sementara itu, lokasi penelitian ini dilakukan di Daerah Istimewa Yogyakarta, yaitu di Universitas Muhammadiyah Yogyakarta, Universitas Ahmad Dahlan, dan Universitas Aisyiyah Yogyakarta.
\end{abstract}

Kata kunci: deradikalisasi, PTMA, IMM, Islam, Pancasila

\begin{abstract}
This study aims to explain the process of deradicalization of students in student organizations, namely the Muhammadiyah Student Association under the guidance of Muhammadiyah Aisyiyah College. Radical understandings and movements that are identical with fanaticism towards Islamic teachings began to develop after the reform era, but their existence is not in line with the ideology of Pancasila, even threatening the essential existence of the country. Students as young people have the potential to threaten this understanding and movement so that higher education units with Islamic teachings have an essential role in coaching through student organizations. Universities based on Islamic values and Muhammadiyah understandings have significantly contributed in producing young generation graduates and building the country. The Muhammadiyah Student Association development as a student organization intended so that students as the nation's next-generation can play a role in building the nation without contradicting the ideology of Pancasila, while also remaining based on Islamic values that are not radical. This study uses a qualitative approach, with primary and secondary data sources. Primary data obtained by conducting in-depth interviews with the leaders of Muhammadiyah Aisyiyah College and Muhammadiyah Student Association, while secondary data was obtained by looking for literature studies in the form of books, journals, and other documents related to deradicalization and the role of Muhammadiyah Aisyiyah College. Meanwhile, the location of this study was carried out in Yogyakarta Special Region, namely at the Universitas Muhammadiyah Yogyakarta, Universitas Ahmad Dahlan, and Universitas Aisyiyah Yogyakarta.
\end{abstract}

Keywords: deradicalization, Muhammadiyah Aisyiyah College, Muhammadiyah Student Association, Islam, Pancasila

Copyright (C2018Universitas Ahmad Dahlan, All Right Reserved

\section{PENDAHULUAN}

Perguruan Tinggi Muhammadiyah Aisyiyah (PTMA) memiliki peran penting dalam membangun karakter mahasiswa berdasarkan nilai-nilai Islam dan tidak bertentangan dengan nilai-nilai Pancasila. Perguruan tinggi ini berfungsi sebagai media pendidikan dalam mengembangkan ilmu pengetahuan sekaligus sebagai memerangi paham radikal yang mengancam eksistensi ideologi negara. Radikalisme yang identik dengan fanatisme ajaran
Islam berkembang melalui sistem pendidikan dan berbagai gerakan atau organisasi kemahasiswaan. Ikatan Mahasiswa Muhammadiyah (IMM) sebagai organisasi kemahasiswaan berbasis ajaran Islam juga memiliki peran penting dalam menjalankan program deradikalisasi di bawah pembinaan dari PTMA. Dengan demikian, PTMA dan IMM menjadi media pendidikan karakter bangsa dan karakter Islam sebagai upaya untuk melakukan deradikalisasi pada mahasiswa. 
Laporan Tempo (2017) menunjukkan tingginya paparan radikalisme di mahasiswa dengan menyebutkan 23,5 persen menyetujui gerakan Negara Islam Irak dan Suriah. Selain itu, 23,4 persen menyetujui kesiapan untuk berjihad mendirikan khilafah. Penangkapan terduga teroris di Perguruan Tinggi Islam mencoreng eksistensi kampus sebagai mengemban tri darma perguruan tinggi. Beberapa penyebab radikalisme terorisme kaum muda seperti persoalan ekonomi, politik, mentalitas, agama dan kultural merupakan hal yang perlu diperhatikan secara serius (Qodir, 2016)

PTMA hadir bukan sekadar ada, namun hadir untuk berkontribusi dalam melahirkan insan cerdas, percaya diri dan berakhlak mulia. Selain itu, ia juga menekankan bahwa masyarakat tak perlu khawatir akan adanya intoleransi atau radikalisme dalam PTMA, karena memiliki visi untuk memajukan dan mengembangkan ilmu pengetahuan serta keterampilan untuk pembangunan dan masyarakat Indonesia dilakukan berdasarkan pada Pancasila dan UUD 1945.

Perkembangan ilmu pengetahuan dan pembangunan di Indonesia yang bersifat dinamis menuntut masyarakat untuk selalu menyesuaikannya dengan ideologi negara, termasuk juga dalam perkembangan radikalisme yang mengancam Pancasila. PTMA sebagai satuan pendidikan dalam hal ini perlu menyesuaikan ilmu pengetahuan dan metode pembelajaran yang diberikan kepada mahasiswa. IMM sebagai organisasi kemahasiswaan juga perlu menyesuaikan paham dan gerakan dalam mengekspresikan dan mengaplikasikan ilmu pengetahuannya.

Perguruan tinggi dan organisasi kemahasiswaan sama-sama berperan dalam menjalankan dan mengevaluasi pendidikan dasar negara dalam membangun pendidikan karakter generasi penerus bangsa. Pendidikan tersebut tidak hanya diperlukan untuk membangun deradikalisasi, tetapi juga untuk membangun persepsi mahasiswa terkait kemajemukan bangsa serta membangun sikap saling menghormati dan menghargai terhadap perbedaan. Ikatan Mahasiswa Muhammadiyah di bawah binaan PTMA perlu mendapatkan bekal pendidikan tentang dasar negara untuk melakukan bela negara, sehingga paham radikal yang masuk dalam organisasi tersebut dapat ditanggulangi.

Latar belakang di atas menunjukkan bahwa perlu adanya penelitian yang terkait dengan deradikalisasi pada organisasi kemahasiswaan di bawah binaan perguruan tinggi yang berlatar belakang nilai-nilai Islam. Dengan demikian, penelitian ini berjudul "Deradikalisasi Organisasi Kemahasiswaan di Perguruan Tinggi Muhammadiyah Aisyiyah di Daerah Istimewa Yogyakarta". Penelitian ini diharapkan dapat menjelaskan proses deradikalisasi IMM pada PTMA di Daerah Istimewa Yogyakarta, sehingga dapat menghasilkan rekomendasi berupa program atau kebijakan bagi PTMA dan IMM yang ada di Indonesia dalam membangun karakter mahasiswa dengan nilai-nilai Al-Islam dan Kemuhammadiyahan yang sejalan dengan nilainilai Pancasila.

\section{METODE PENELITIAN}

Penelitian ini menggunakan model pendekatan kualitatif. Penelitian kualitatif adalah penelitian yang menghasilkan prosedur analisis yang tidak menggunakan prosedur analisis atau cara kuantifikasi lainnya. Penelitian kualitatif didasarkan pada upaya membangun pandangan mereka yang diteliti yang rinci, dibentuk dengan kata-kata, gambaran holistik dan rumit (Moleong, 2012: 6). Pendekatan kualitatif ini dijelaskan dengan metode deskriptif, yaitu sebagai prosedur pemecahan masalah yang diselidiki dengan menggambarkan keadaan subyek/obyek penelitian (seseorang, lembaga, masyarakat dan lain-lain) pada saat sekarang berdasarkan fakta-fakta yang tampak (Nawawi, 2012: 67). Penelitian ini berupaya menggambarkan fakta-fakta terkait proses deradikalisasi pada mahasiswa, baik yang dilakukan oleh PTMA maupun IMM.

Subyek yang menjadi penelitian dalam hal ini adalah PTMA dan IMM di Daerah Istimewa Yogyakarta, karena merupakan pusat usaha Muhammadiyah dalam bidang pendidikan. Hal ini sesuai dengan pendapat Nawawi (2012:167), yang menjelaskan bahwa teknik pengambilan sampel yang disesuaikan dengan tujuan penelitian disebut sebagai teknik purposive sampling, yaitu sampel atau informan yang sesuai dengan kriteria-kriteria tertentu yang ditetapkan berdasarkan tujuan tersebut. Teknik ini menentukan bahwa informan yang akan diteliti adalah pimpinan PTMA dan IMM yang berada di wilayah DIY, yaitu di Universitas Muhammadiyah Yogyakarta, Universitas Ahmad Dahlan, dan Universitas Aisyiyah Yogyakarta.

Teknik pengumpulan data dalam penelitian ini dilakukan dengan berdasarkan pada sumber primer dan sekunder, dengan menentukan informan penelitian yang representatif sesuai dengan objek penelitian. Data utama/primer bersumber dari hasil wawancara dan pengamatan dengan upaya kegiatan melihat, mendengar dan bertanya, yang dilakukan pada objek penelitian (Moleong, 2010). Data kedua/sekunder bersumber dari sumber tertulis seperti buku dan majalah ilmiah, arsip, dokumen pribadi, dan dokumen resmi (Moleong, 2010).

Data-data yang telah diperoleh melalui proses penelitian di atas selanjutnya ditindaklanjuti dengan analisis data, agar data-data terkait deradikalisasi yang dilakukan oleh PTMA dan IMM dapat bersifat objektif. Analisis data terdiri dari tiga alur yang 
terjadi secara bersamaan. Pertama, yaitu reduksi data sebagai bentuk analisis yang menajamkan, menggolongkan, mengarahkan, dan membuang yang tidak perlu (Miles \& Huberman, 1992). Kedua, penyajian data yaitu sekumpulan informasi tersusun yang memberi kemungkinan adanya penarikan kesimpulan dan pengambilan tindakan. Ketiga, menarik kesimpulan, yaitu verifikasi pemikiran kembali yang melintas dalam pikiran penganalisis selama penulisan, suatu tinjauan ulang pada catatan lapangan untuk mengembangkan kesepakatan intersubjektif.

Data-data terkait permasalahan radikalisme dan studi deradikalisasi yang telah dianalisis melalui proses analisis data di atas, selanjutnya dilakukan uji keabsahan data, agar data yang telah diolah dapat diujikan kebenarannya dan tidak bersifat manipulatif ataupun subjektif. Uji keabsahan data yang diperoleh oleh peneliti dilakukan dengan teknik triangulasi. Triangulasi menjadi cara yang terbaik untuk menghilangkan perbedaan konstruksi kenyataan dalam konteks suatu studi pada waktu mengumpulkan data tentang berbagai kejadian dan hubungan dari berbagai pandangan (Moleong, 2010). Peneliti dapat mengecek kembali temuan dengan membandingkan berbagai sumber, metode dan teori.

\section{HASIL DAN PEMBAHASAN}

\section{Radikalisme Pasca Reformasi}

Pasca era Reformasi yang telah membuka keran kebebasan bagi munculnya berbagai ideologi dan pergerakan, beberapa kelompok radikal dengan mengatasnamakan demokrasi, telah memanfaatkan angin kebebasan ini untuk menunjukkan eksistensi dirinya di Indonesia (Darraz, 2013). Paham dan gerakan masyarakat yang berbasis nilai-nilai Islam banyak bermunculan pasca runtuhnya Orde Baru melalui sistem pendidikan di Indonesia, sebagian masyarakat muslim dalam negara demokrasi tersebut merasa berhak untuk menjalankan syariatnya dalam berbangsa dan bernegara, sehingga dalam penyelenggaraannya bertentangan dengan ideologi negara. Paham ini pun semakin menyebar lebih luas dan kompleks hingga masuk di perguruan tinggi, dengan menyasar para mahasiswa sebagai generasi muda yang sedang mencari jati diri.

Radikalisme mengerucut pada paham yang dilekatkan pada golongan keagamaan yang memiliki paham terlalu keras dalam menyikapi suatu persoalan. Hal ini biasanya tumbuh dari latar belakang karena merasa terpojok karena tekanan rezim dari faktor ekonomi ataupun politik kemudian memunculkan konflik. Radikalisasi tersebut merupakan proses bagi mereka untuk menanamkan nilai yang mereka pahami untuk orang lain dalam konteks pemaksaan, dengan pendekatanpendekatan agitasi dan provokasi yang menjadi proses mereka. Dalam konteks keislaman dan keindonesiaan, radikalisasi menjadi ancaman karena konsensus negara Indonesia sendiri berdasarkan pada Pancasila dan tidak berdasarkan pada basis salah satu agama. Sementara itu, deradikalisasi itu fokus pada bagaimana orang itu tidak lagi percaya pada identitas dan nilai yang ada pada dirinya sehingga ikut kepada identitas yang lain.

Jika paham radikal yang selama ini tidak menerima paham yang lain, namun tidak mengganggu paham yang lain, tidak mengganggu persatuan, kebersamaan, dan keberagaman maka tidak menjadi masalah. Kata-kata radikalisme yang saat ini muncul adalah untuk menyerang Islam, yang seolah ada perbedaan pandangan Islam. Sementara itu, deradikalisasi digunakan untuk kepentingan pemetaan orang dalam melaksanakan syariatnya. Jadi, isu deradikalisme ini muncul karena adanya konflik kepentingan, baik untuk kepentingan pribadi ataupun golongan.

Umat Islam Indonesia umumnya bersikap positif terhadap modernitas, namun kelompok garis keras justru bersikap reaksioner. Kelompok garis keras menganut paham absolutisme dan tidak berkompromi, intoleran terhadap berbagai sudut pandang, bahkan keragaman dianggap sebagai kontaminasi kebenaran yang diyakini (Wahid, 2009). Radikalisme di negara ini tidak dapat diterima oleh bangsa Indonesia, karena hal tersebut bertentangan dengan Pancasila yang bersifat terbuka. Sistem pendidikan memiliki posisi yang strategis untuk memberikan penawar terhadap kontaminasi tersebut, sehingga nilai-nilai Islam dapat berjalan tanpa harus berlawanan dengan negara.

Proses radikalisasi yang menyasar pada mahasiswa sebagai generasi muda penerus bangsa semakin mengancam eksistensi ideologi Pancasila, dan hal ini perlu segera ditanggulangi secara bijaksana melalui satuan pendidikan. Perguruan tinggi berbasis Islam memiliki pengaruh penting dalam penanggulangan bahaya radikalisme tersebut. Hal ini karena sifat radikal sebagaimana dijelaskan di atas lebih cenderung pada nilai-nilai Islam yang fanatik, oleh karena itu peran perguruan tinggi ini perlu mempertegas bahwa paham Pancasila sebagai ideologi negara tidak bertentangan dengan paham Islam.

\section{Peran PTMA dalam Menanggulangi Radikalisme}

Perguruan Tinggi Muhammadiyah Aisyiyah sebagai basis terbesar dalam organisasi masyarakat Islam memegang peranan penting dalam menjaga dinamika ketahanan nasional dari radikalisme. Perguruan tinggi ini berdasarkan pada nilai-nilai $\mathrm{Al}$ Islam dan Kemuhammadiyahan, sehingga arah orientasi lulusan mahasiswanya mengarah pada 
basis paham berdasarkan nilai-nilai tersebut. Namun demikian, Muhammadiyah sebagai pihak pengelola dari satuan pendidikan tersebut memiliki visi dan misi yang sejalan dengan Negara Kesatuan Republik Indonesia dalam mewujudkan negara yang baik, adil dan sejahtera.

Muhammadiyah pada awal sejarahnya membawa misi mempersiapkan masyarakat Muslim di tanah air menyongsong kehidupan modern/urban. Muhammadiyah merupakan kekuatan progresif tetapi tidak radikal dalam tindakan, walaupun pemikiran-pemikirannya mungkin dianggap revolusioner untuk ukuran saat itu. Muhammadiyah menjalankan misi perubahan bukan melalui revolusi fisik atau mengandalkan kekerasan, melainkan melalui gerakan dakwah dan pendidikan (Bayuni, 2010). Sikap Muhammadiyah ini juga tercermin dalam Amal Usaha Muhammadiyah melalui PTMA sebagai satuan pendidikan yang membangun kehidupan modern dan berkemajuan, yang turut serta dalam mencerdaskan kehidupan bangsa.

Kedudukan lembaga (biro/divisi/bidang) kemahasiswaan di PTMA tentu memiliki peran penting dalam mengendalikan pengaruh pahampaham yang berbahaya bagi organisasi kemahasiswaan. Posisinya sangat jelas, karena bersangkutan legitimasi di perguruan tinggi, sehingga jika terdapat permasalahan akan langsung dipotong pada jalur tersebut. Peraturan dari pemerintah juga melarang adanya paham radikal tumbuh di perguruan tinggi. Lembaga kemahasiswaan memberikan pemahaman kebangsaan pada saat Mataf (Masa Taaruf) sebagai poin materi yang harus disampaikan, termasuk perilaku menyimpang lainnya seperti bahaya narkoba, dengan mendatangkan pematerinya langsung dari Kapolda DIY. Namun demikian, lembaga kemahasiswaan sejauh ini menilai belum ada formula pasti yang bisa menjaga saat mahasiswa masuk sampai dengan selesai kuliah, agar tidak terkontaminasi dalam dunia radikal.

Legalitas keberadaan suatu organisasi kemahasiswaan di perguruan tinggi ini tentu sangat penting di tengah berkembangnya pergerakanpergerakan yang bersifat militan dan berbasis pada gerakan akar rumput. Sifat dari organisasi tersebut tidak banyak diketahui oleh publik, namun keberadaannya dapat dikatakan membahayakan nilai-nilai yang telah dibangun di perguruan tinggi yang telah bersinergi dengan nilai-nilai kenegaraan. Dengan demikian, peran Lembaga kemahasiswaan dalam melegalkan organisasi-organisasi kemahasiswaan menjadi penting untuk mengoreksi paham dan gerakan yang berada dalam perguruan tingginya. Bahkan keberadaan organisasi yang bersifat akar rumput dan tidak legal yang berdasarkan nilai-nilai yang tidak satu visi dengan perguruan tinggi dapat dibubarkan secara tegas.

Lembaga kemahasiswaan di UAD mengajak para mahasiswa untuk berdiskusi bersama dan melihat fakta yang ada dengan berbagai pemikiran, dengan adanya ruang ini mahasiswa akan dapat memahami hal yang terjadi. Organisasi IMM UAD memiliki kajian keagamaan rutin yang berperan aktif, baik untuk UAD sendiri ataupun kepada masyarakat. Kebijakan kemahasiswaan yang diberikan kepada mahasiswa yang baru masuk UAD adalah kegiatan PPK (Program Pengenalan Kampus) dan Masta (Masa Taaruf) sebagai pembekalan tentang organisasi di kampus maupun persiapan di dunia kerja.

Waktu masuk pada awal perkuliahan di perguruan tinggi menjadi momen penting untuk membangun konstruksi berfikir mahasiswa secara fundamental, karena pada masa awal tersebut mahasiswa masih berpikiran general dan masih rawan terhadap penyusupan nilai-nilai ekstrem yang belum dipahami secara mendasar oleh mahasiswa baru. Program masa orientasi di awal perkuliahan dilibatkan dengan nilai-nilai yang bermuatan materi keislaman dan keindonesiaan, sehingga di Perguruan Tinggi Muhammadiyah Aisyiyah yang berbasis nilai Islam tetap sejalan dengan pemikiran kenegaraan. Dengan demikian, jika dalam perkuliahan berikutnya mahasiswa mendapatkan paham-paham yang radikal dari suatu pergerakan atau organisasi kemahasiswaan dapat ditangkal dengan pemikiran yang logis yang telah ditanamkan pada saat masa orientasi perkuliahan.

Tugas pokok dan fungsi perguruan tinggi di atas sesuai dengan prinsip Muhammadiyah dalam mengimbangi nilai kenegaraan dan keagamaan, sehingga tidak bersifat radikal. Hal ini dapat dilihat pada Pedoman Pimpinan Pusat Muhammadiyah Nomor 2/PED/I.0/B2012 yang menjelaskan bahwa Perguruan Tinggi Muhammadiyah merupakan amal usaha Muhammadiyah bidang pendidikan yang dijiwai dan dilandasi nilai-nilai $\mathrm{Al}$ Islam dan Kemuhammadiyahan pada tataran ideologis-filosofis maupun praktis-aplikatif, serta menjadi salah satu kekuatan dan kesinambungan Muhammadiyah dalam mencapai tujuannya sebagai gerakan dakwah dan tajdid yang melintasi zaman.

Peran PTMA dalam hal ini jika menemukan mahasiswa yang radikal bahkan mengarah pada tindakan kriminal, maka hal yang pertama yang akan dilakukan adalah dapat melakukan pembinaan ataupun jika perlu akan mengundang orang tua/walinya. Namun jika memang mahasiswa tersebut tetap pada pendirian dalam radikalismenya, maka pihak perguruan tinggi dapat 
mengeluarkannya, dan akan menyerahkannya kepada pihak yang berwenang.

Perguruan Tinggi Muhammadiyah Aisyiyah sebagai usaha dalam bidang pendidikan yang dijiwai dan dilandasi nilai-nilai Al-Islam dan Kemuhammadiyahan pada tataran ideologisfilosofis maupun praktis-aplikatif berupaya membangun karakter generasi muda sebagai generasi penerus bangsa. Namun, mahasiswa pada muda ini perlu diberikan pembinaan karakter sesuai dengan visi perguruan tinggi dalam membangun karakter keislaman dan kenegaraan. Mubarak (2013: 196) menjelaskan bahwa usia muda yang merupakan fase pencarian jati diri ditandai dengan rasa penasaran serta hasrat tinggi mencoba berbagai pengalaman religiositas menjadi ruang masuknya berbagai paham keagamaan. Arus keagamaan radikal memiliki pengaruh signifikan dengan kegiatan keagamaan yang menyuarakan aspirasi fundamentalisme Islam, seperti pembentukan Negara Islam atau Khilafah Islamiah.

Mahasiswa sebagai generasi penerus bangsa memiliki peran penting dalam memahami karakter kenegaraan yang telah merdeka dari penjajah dengan struktur pemikiran negarawan yang nasionalis dan multikultural. Konsep kenegaraan yang telah menjadi konstitusi negara tidak dapat dengan konstruksi dengan konsep Negara Khilafah atau negara berdasarkan syariat agama Islam. Posisi mahasiswa dalam hal ini sangat menentukan arah pergerakan negara di masa mendatang, sehingga sikap kritis dan empati mahasiswa menjadi hal yang perlu diperhatikan oleh institusi perguruan tinggi dan organisasi kemahasiswaan sebagai media pembelajaran yang sangat menentukan arah paham dan pemikiran mahasiswa ke depan.

\section{Gerakan Kemahasiswaan dalam Menyikapi Radikalisme}

Mahasiswa yang tergabung dalam gerakan kemahasiswaan dalam PTMA atau yang disebut Ikatan Mahasiswa Muhammadiyah memiliki posisi penting dalam membangun karakter pemuda sebagai generasi penerus bangsa. Gerakan pemuda dari PTMA ini berperan dalam menanggulangi radikalisme dengan membangun nilai-nilai keislaman yang diimbangi dengan nilai-nilai kenegaraan. Berkaitan dengan hal tersebut, Mustaqim \& Tohari (2010, hal. 6) mengungkapkan bahwa "gerakan pemuda yang perlu dibentuk adalah lebih mengedepankan pada pembentukan karakter, laboratorium kepemimpinan, dan membentuk pemahaman terhadap permasalahan lokal serta global, dan kontribusi dalam tataran ide maupun aksi". Pemuda itu sendiri menurut Matara (2013, hal. 10) adalah "orang yang melakukan perjuangan untuk membangun pribadi yang mandiri menjadi terlibat secara sosial, yaitu bahwa seorang pemuda seharusnya terlibat dalam pergaulan sosial, berupa kesadaran bahwa dirinya merupakan bagian dari lingkungan sosialnya".

Media pergerakan mahasiswa yang terdapat pada Ikatan Mahasiswa Muhammadiyah (IMM) dikonstruksi dengan pemikiran-pemikiran keagamaan dan kenegaraan. Konsep keislaman dan keindonesiaan menjadi hal penting untuk disejajarkan dalam paham dan pergerakan kemahasiswaan, sehingga dalam satu sisi tidak menjadi pergerakan yang bersifat ke kanan (ekstrem religius) dan tidak pula menjadi pergerakan yang ke kiri (ekstrem komunis). Radikalisme menjadi makna ekstrem untuk mendefinisikan dua klasifikasi pemikiran tersebut, namun dalam realisasinya banyak penafsiran yang masih awam untuk mendeskripsikan paham tersebut. Dengan demikian, dalam realisasinya itu pula banyak suatu pergerakan atau organisasi kemahasiswaan yang tidak sadar bahwa dirinya telah melakukan banyak hal tanpa memahami secara mendasar dari makna filosofis pergerakan yang telah diperjuangkannya.

Pandangan IMM terhadap radikalisme dalam ormawa lebih mengarah agar mahasiswa bergerak secara intektual, religiositas, dan humanitas. Pergerakan pada bidang tersebut dilakukan agar tidak termasuk golongan-golongan orang ataupun organisasi mahasiswa yang secara radikal. Religiositas menurutnya adalah sebagai bentuk ibadah, yang merupakan hubungan habluminallah, habluminannasi, dan habluminalam. Hal tersebut menjadi kajian yang diskusikan dengan anggotaanggota IMM untuk membentuk suatu manusia yang berguna bagi Nusa dan Bangsa.

Pergerakan kemahasiswaan melalui IMM dalam menghadapi radikalisme dituntut untuk berfikir ke arah pemikiran yang kritis, yang mengarahkan mahasiswa pada hal yang bersifat intektual, religiositas, dan humanitas. Hal ini perlu dipahami bahwa paham radikal mengaitkan dua kutub yang berbeda, yaitu antara pemikiran berdasarkan nilai-nilai dalam agama Islam dengan nilai-nilai dalam ideologi Pancasila, sehingga paham fundamental satu agama sangat berpotensi menimbulkan perpecahan besar jika dijadikan paham dasar negara yang bersifat plural. Prinsip pemeliharaan pikiran dengan tidak membenturkan paham keagamaan dengan kenegaraan inilah yang sampai saat ini terus diujikan, baik melalui muatan materi pendidikan hingga dalam bentuk gerilya dengan aksis terror dan sebagainya.

Sementara itu, Koordinator Komisariat IMM UAD bahwa seorang kader dalam ormawa perlu membawa kepentingan IMM, yaitu menjaga amal usaha Muhammadiyah supaya tidak digunakan secara sewenang-wenang oleh orang-orang yang tidak mengenal Muhammadiyah dan tidak 
mengakui Muhammadiyah. Radikal sama artinya dengan fundamental, yaitu mengakar dari bawah, benar-benar dihayati ditiru totalitas dan kerja keras tidak setengah-setengah. Sisi positif yang dapat diambil dalam hal ini adalah ketika seorang mahasiswa mengaku sebagai kader IMM, maka segala aturan yang ada di IMM akan diakui dan dipatuhi.

Peran yang sudah dilakukan IMM menurut Koordinator Komisariat di UNISA di antaranya adalah pelaksanaan kajian-kajian keislaman dan kebangsaan. Organisasi IMM juga mencoba menyebar ke seluruh penjuru organisasi yang ada di perguruan tinggi, agar tetap menjaga ideologi Muhammadiyah. Salah satunya dengan diaspora kader, diaspora mahasiswa-mahasiswa yang ada di IMM dikirim ke organisasi Badan Eksekutif Mahasiswa (BEM) Universitas dan Fakultas, serta Himpunan Mahasiswa Jurusan (HMJ) secara berkelanjutan.

Pemikiran mahasiswa dalam IMM perlu memperhatikan secara mendasar melalui pemahaman ideologi Muhammadiyah secara menyeluruh. Hal ini penting dilakukan sebagai bentuk loyalitas generasi muda terhadap organisasi Islam yang besar dan telah berkontribusi besar juga dalam membangun peradaban negara hingga saat ini. Pergerakan mahasiswa yang akan melanjutkan pemikiran negarawan di masa depan sangat penting untuk memahami diskursus pemahaman antara persepsi religius dengan nasionalis. Dengan demikian, konsepsi radikalisme akan terpecahkan dengan sendirinya ketika pemikiran kritis mahasiswa ini mampu mengintegrasikan pemikiran keagamaan untuk membangun peradaban negara yang sejahtera.

\section{Deradikalisasi Organisasi Kemahasiswaan}

Hal yang perlu diperhatikan sebelum melakukan deradikalisasi adalah membuat definisi yang sama terkait dengan radikalisasi dan perlu memperjelas penggunaan dari istilah radikalisasi. Mahasiswa dalam hal ini selalu menjadi alat, karena mereka memiliki mimpi untuk memperbaiki tatanan ekonomi politik Indonesia ke depan. Sementara itu, pendekatan yang dapat digunakan untuk menanggulangi radikalisme dilakukan dengan pendekatan budaya, yaitu mengembalikan fungsi Islam pada aslinya. Menurutnya, Islam datang bukan untuk meresahkan masyarakat, akan tetapi untuk mengajak rahmatan lill'alamin, jadi sesuai dengan perkembangan zaman.

Berdasarkan pada maksud deradikalisasi di atas, pada hakikatnya perlu dipahami terlebih dahulu dengan makna kata deradikalisasi tersebut. Secara tata bahasa, maka dapat dimaknai sebagai proses yang menegasikan dari segala sesuatu yang bersifat ekstrem dan fundamental. Pada saat bersamaan, perlu juga dipahami perbedaan antara nilai Islam dengan nilai Pancasila, yaitu antara agama sebagai syariat dengan ideologi sebagai sosial budaya. Dengan demikian, arah pemikiran deradikalisasi ini semakin jelas tujuannya, yaitu menegasikan pemikiran atau paham yang tertutup, bukan menyalahkan syariat dalam nilai agama itu sendiri, dan bukan pula memaksakan syariat agama sebagai modal alasan untuk menggantikan ideologi atau pemikiran manusia sebagai tatanan sosial budaya dalam kehidupan bernegara.

Hal terpenting dalam deradikalisasi tentang
cara mahasiswa paham dengan nilai kemuhammadiyahan. Radikalisasi ini terjadi pada saat berhubungan dengan politik yang selalu muncul, sedangkan persoalan yang perlu ditanamkan adalah lebih pada konteks pemahaman dan pemikiran Islam, fikih, akidah, dan akhlak. Gerakan radikal ini dinilai masih relatif aman dalam PTMA, karena kesibukan kuliah para mahasiswa yang tidak sempat memikirkan ke arah radikal.

Penekanan deradikalisasi lebih mengutamakan pengembangan soft skill dari pada pendidikan tentang deradikalisasi. Pendidikan tentang soft skill akan sangat bermanfaat bagi mahasiswa ke depan, sehingga kesibukan ini akan mengalihkan perhatian mahasiswa untuk mengembangkan kapasitas dirinya dari pada sibuk mempermasalahkan perbedaan paham radikal. Pada sisi lain munculnya radikalisme hingga pemberontakan itu disebabkan karena tidak adanya kesejahteraan dan ketidakpuasan terhadap pemerintah. Radikalisasi menjadi bahan introspeksi bagi pemerintah untuk mencari penyebab paham tersebut muncul, yaitu lebih kepada pembangunan dan keterbukaan pemerintah untuk mewujudkan kesejahteraan sosial.

Konsep penafsiran sederhana terkait deradikalisasi dapat diartikulasikan dengan pembangunan keadilan dan kesejahteraan dalam kehidupan bermasyarakat, berbangsa, dan bernegara. Pemikiran fundamental dan ekstrem yang kontroversial dengan paham pemikiran yang lain dalam kasus radikalisme ini muncul ke permukaan dikarenakan tuntutan terhadap ketidakadilan dan ketidaksesjahteraan yang dialami seorang maupun sekelompok orang.

Sikap kritis dalam pemikiran dan pergerakan yang perlu ditanamkan dalam organisasi kemahasiswaan yang revolusioner dalam upaya pembangunan politik, ekonomi, sosial, hingga pertahanan keamanan negara menjadi lebih menarik dari pada bersikap radikal. Mahasiswa dalam hal ini dituntut untuk produktif melalui pemikiran dan pergerakan yang berkualitas untuk mengembangkan kapasitas dan kapabilitas dirinya, sehingga dapat 
menjadi inspirasi dalam berkontribusi pembangunan negara yang lebih sejahtera.

\section{Analisis Strategi Deradikalisme Organisasi Kemahasiswaan}

Bahaya radikalisme dan ekstremisme sebagaimana bahasan di atas menjadi bahan pertimbangan mendasar bahwa perlunya strategi dalam rangka pembangunan kebijakan deradikalisasi. Upaya ini memerlukan analisis mendalam terkait posisi PTMA maupun IMM dalam menghadapi radikalisme, mulai dari analisis kekuatan (strength), kelemahan (weaknesses), ancaman (threats), dan peluang (opportunities) yang dimiliki. Analisis keempat hal tersebut dilakukan untuk mengetahui apa saja hal-hal yang dapat dilakukan oleh PTMA maupun IMM dengan tahapan-tahapan yang jelas dan strategis.

Berdasarkan analisis kekuatan di UNISA adalah legitimasi. Hal ini karena ketika gerakan radikal masuk ke perguruan tinggi, pihaknya dapat dengan segera membubarkannya, sehingga jika ada organisasi baru yang terlarang dapat dicegah oleh universitas. Perguruan Tinggi Muhammadiyah Aisyiyah memiliki wadah IMM sebagai media organisasi kemahasiswaan, dan sejauh ini tidak memiliki susupan radikalisme. Jika pun ada paham radikal yang masuk, pihaknya bisa memastikan hal tersebut akan segera dipotong ataupun dicegah. UAD juga memiliki kekuatan yang sama, yaitu melakukan kontrol lembaga, karena dalam setiap kegiatan IMM selalu ada pengecekan dan persetujuan dari biro kemahasiswaan yang harus sesuai dengan standar operasional prosedur (SOP).

Kendala dalam menghadapi paham radikal ini adalah karena organisasinya yang berjejaring, serta membawa organisasi sendiri dengan membuat kelompok seperti Lembaga Dakwah Kampus (LDK), sedangkan dalam PTMA seharusnya lembaga tersebut berada di bawah IMM. Sementara itu ada dua hal yang menjadi kelemahan dari gerakan radikal, yaitu mereka membentuk kelompok dan bermain di akar rumput sehingga pihak perguruan tinggi tidak tahu, serta ada kemungkinan mereka melakukan penyusupan sehingga pihak perguruan tinggi tidak mungkin untuk melakukan pendekatan satu per satu Namun UMY memfasilasi mahasiswa untuk meminimalisir paham radikal tersebut, yaitu membentuk kanalisasi untuk mengalihkan energi-energi mahasiswa dalam 35 UKM, organisasi mahasiswa HMJ, BEM fakultas dan universitas yang jumlahnya lebih dari 90 organisasi internal kampus.

Pada sisi lain, beberapa peluang yang bisa dimanfaatkan oleh PTMA, pertama ada adalah dengan menguatkan organisasi yang sudah ada dan mengembangkannya. Kedua, melakukan kerja tim baik mahasiswa yang belum ataupun yang sudah lulus. Ketiga, PTMA memiliki Lembaga Pengkajian dan Pengamalan Islam (LPPI) yang dapat menguatkan nilai secara ke-Islam-an, dan memiliki Lembaga Admisi universitas yang dapat menyortir data informasi sejak awal masuk. Sementara itu dari Kemenristekdikti juga telah memberikan surat edaran yang menjadi peluang besar untuk menanggulangi radikalisme pada organisasi mahasiswa. Peluang lainnya adalah dengan mengembangkan potensi minat dan bakat mahasiswa, dan secara eksternal PTMA juga bekerja sama dengan pihak kepolisian provinsi maupun kabupaten/kota untuk menjaga keamanan dari bahaya radikalisme.

Berkaitan dengan ancaman, yang menjadi tantangan adalah media sosial yang digunakan oleh gerakan radikal untuk menarik mahasiswa lain ke arah yang ekstrem. Ancaman lainnya ketika muncul isu hoax melalui sosial media, dan mahasiswa tidak bisa menyaring bahaya radikal. Namun demikian, sebenarnya menjadi ancaman dan kendala yang sebenarnya bagi mahasiswa adalah sifat hedonisme, bukan radikalisme.

Berdasarkan analisis kekuatan, kelemahan, peluang dan tantangan di atas, maka strategi yang bisa dilakukan adalah dengan menggunakan datadata saat penerimaan mahasiswa baru untuk diproses dan dilihat pada saat Orientasi Studi Dasar Islam di PTMA. Studi ini mengenalkan Islam yang damai dan berkemajuan. Data-data kemahasiswaan tersebut juga digunakan untuk diidentifikasi, kemudian melakukan pendekatan persuasif agar mahasiswa yang memiliki paham radikal dapat berubah, dan pendekatan represif dengan menyerahkannya ke pihak yang berwenang.

Strategi yang lain adalah dengan mengalihkan perhatian mahasiswa kepada hal-hal yang positif, seperti mengembangkan minat, bakat dan potensinya pada unit-unit kemahasiswaan ada di perguruan tinggi. Mahasiswa dan pihak PTMA juga dapat memfokuskan diri untuk meraih prestasiprestasi, dengan mengikuti kompetisi dalam bidang akademik maupun kreativitas yang akan bermanfaat untuk perguruan tinggi maupun mahasiswa itu sendiri. Dengan demikian, pengaruh paham radikal tidak akan berdampak apapun pada mahasiswa, karena dirinya menyadari bahwa partisipasinya dalam unit-unit kemahasiswaan dan prestasi yang diraihnya jauh lebih bermanfaat bagi mahasiswa.

\section{KESIMPULAN}

Berdasarkan hasil dari analisis di atas, maka dapat disimpulkan bahwa proses radikalisasi yang menyasar pada mahasiswa sebagai generasi muda penerus bangsa semakin mengancam eksistensi ideologi Pancasila, dan hal ini perlu segera ditanggulangi secara bijaksana melalui satuan 
pendidikan. Perguruan tinggi berbasis Islam memiliki pengaruh penting dalam penanggulangan bahaya radikalisme tersebut. Hal ini karena sifat radikal sebagaimana dijelaskan di atas lebih cenderung pada nilai-nilai Islam yang fanatik, oleh karena itu peran perguruan tinggi ini perlu mempertegas bahwa paham Pancasila sebagai ideologi negara tidak bertentangan dengan paham Islam. Perguruan Tinggi Muhammadiyah Aisyiyah berdasarkan pada nilai-nilai Al-Islam dan Kemuhammadiyahan, sehingga arah orientasi lulusan mahasiswanya mengarah pada basis paham berdasarkan nilai-nilai tersebut. Namun demikian, Muhammadiyah sebagai pihak pengelola dari satuan pendidikan tersebut memiliki visi dan misi yang sejalan dengan Negara Kesatuan Republik Indonesia dalam mewujudkan negara yang baik, adil dan sejahtera.

Deradikalisasi organisasi kemahasiswaan di Perguruan Tinggi Muhammadiyah Aisyiyah Daerah Istimewa Yogyakarta dapat dilakukan dengan beberapa strategi. Pertama, penanaman nilai keislaman dan keindonesiaan pada saat awal perkuliahan melalui masa orientasi mahasiswa dalam program masa taaruf, sehingga mahasiswa mendapatkan konstruksi yang kritis dalam pembangunan bangsa dan negara. Kedua, lembaga kemahasiswaan perguruan tinggi melakukan verifikasi setiap organisasi yang legal ataupun tidak legal untuk memastikan organisasi kemahasiswaan sejalan dengan visi perguruan tinggi dan ideologi negara, sehingga apabila terdapat hal-hal yang bertentangan dengan hal tersebut maka organisasi yang bersangkutan dapat secara tegas dibubarkan. Ketiga, mengalihkan perhatian mahasiswa melalui kegiatan-kegiatan yang positif di IMM ataupun unit kemahasiswaan lainnya, sehingga minat dan bakat yang menjadi potensi mahasiswa dapat difasilitasi dan dapat berkembang dengan optimal.

\section{UCAPAN TERIMA KASIH}

Ucapan terima kasih peneliti sampaikan kepada Universitas Aisyiyah Yogyakarta yang telah menyelenggarakan program penelitian ini, sehingga peneliti dapat melaksanakan dan menyelesaikan penelitian ini hingga dapat dipublikasikan. Terima kasih juga peneliti sampaikan kepada Jurnal Citizenship sebagai media publikasi Pendidikan Pancasila dan Kewarganegaraan yang telah berkenan menerima naskah publikasi dari hasil penelitian saya, sehingga peneliti berharap artikel penelitian ini dapat bermanfaat bagi seluruh pimpinan dan mahasiswa yang ada di Perguruan Tinggi Muhammadiyah Aisyiyah seluruh Indonesia.

Peneliti juga mengucapkan terima kasih untuk Lembaga Kemahasiswaan dan Koordinator Komisariat Ikatan Mahasiswa Muhammadiyah yang ada di Universitas Aisyiyah Yogyakarta, Universitas Muhammadiyah Yogyakarta, dan Universitas Ahmad Dahlan, sehingga penelitian ini dapat memperoleh data yang lengkap dan sesuai dengan tujuan penelitian..

\section{DAFTAR PUSTAKA}

Bayuni, E. M. (2010). Muhammadiyah, antara gerakan progresif dan konservatif. MAARIF Arus Pemikiran Islam dan Sosial, 5(1), 54-60. Diambil dari http://muhammadiyahstudies.blogspot.com/ 2011/02/muhammadiyah-antara-gerakanprogresif.html

Darraz, M. A. (2013). Radikalisme dan lemahnya peran pendidikan kewargaan. MAARIF Arus Pemikiran Islam dan Sosial, 8(1).

Matara. (2013). Psikologi pemuda. Yogyakarta: Mitra Pustaka Nurani.

Miles, M. B., \& Huberman, A. M. (1992). Analisis data kualitatif. Jakarta: Universitas Indonesia Press.

Moleong, L. J. (2010). Metode penelitian kualitatif. Bandung: PT. Remaja Rosdakarya.

Mustaqim, G., \& Tohari, H. M. (2010). Pemuda membangun bangsa dari desa. Bandung: Synersia Pub. Diambil dari https://books.google.co.id/books?id=sMDcZ wEACAAJ

Qodir, Z. (2016). Kaum muda, intoleransi, dan radikalisme Agama. Jurnal Studi Pemuda, 5(1), 429-445.

Tempo. (2017). Survei Alvara: 20 persen pelajar dan mahasiswa rela berjihad. Diambil 17 Juli 2019, dari https://nasional.tempo.co/read/1029476/sur vei-alvara-20-persen-pelajar-dan-mahasiswarela-berjihad

Wahid, A. (Ed.). (2009). Ilusi negara Islam: Ekspansi gerakan Islam transnasional di Indonesia. Jakarta: The Wahid Institute. 